\title{
Romance, memória e insônia na noite antuniana: uma leitura de Ontem não te vi em Babilônia
}

\author{
Maristela Kirst de Lima Girola*
}

\begin{abstract}
Resumo: Este ensaio procura mostrar de que forma o autor incorpora esteticamente temas sociais e políticos em seu texto romanesco, como a repressão e a violência na época da ditadura salazarista, em Portugal. Analisa-se os recursos narrativos empregados por Lobo Antunes para a composição do romance, ressaltando algumas características estéticas que marcam a sua produção como a desestruturação da narrativa tradicional, a variedade de vozes narradoras e a fragmentação do discurso da memória, que exigem a atenção do leitor.
\end{abstract}

Palavras-Chave: Literatura Portuguesa; Memória; Romance; Personagem; Polifonia.

\begin{abstract}
This essay aims at showing how the writer utilizes social and political topics in the novel, such as repression and violence during the salazarist period, in Portugal. This work analyzes the narrative resources utilized by Lobo Antunes in the composition of the novel, focusing on some esthetic characteristics like destructuralization of the traditional narrative, polyphony and fragmentation of the memory discourse, all of which demand the reader's attention.
\end{abstract}

Keywords: Portuguese Literature; Memory; Novel; Character; Polyphony.

Ontem não te vi em Babilônia, romance de António Lobo Antunes, foi publicado, em Portugal, em 2006. Com esta obra, o escritor parece ter alcançado o desenvolvimento de uma escrita ainda mais complexa em relação à construída a partir de Não entres tão depressa nessa noite escura, romance publicado em 2000. O próprio Lobo Antunes, em entrevistas ${ }^{1}$, tem declarado que cada vez menos lhe interessa contar uma história. O que tem se acentuado nesta fase "noturna" da obra antuniana é a construção de personagens que se debruçam sobre o passado, sobre o sentido de suas vidas, através de um discurso fragmentado em várias vozes, entrecortado por pensamentos, rememorações, frases inacabadas, constituindo um fluxo mental, uma liberação por meio da palavra de conteúdos psíquicos reprimidos. Esses conteúdos dos sujeitos relacionam-se, muitas vezes, a traumas históricos da sociedade portuguesa contemporânea, como a repressão e a violência do período ditatorial salazarista.

\footnotetext{
* Doutoranda em Teoria da Literatura pela PUCRS. Bolsista CAPES e Pesquisadora do Núcleo de Estudos Lusófonos (NEL) da PUCRS. Mestre em Teoria da Literatura pela PUCRS. Especialista em Literatura Brasileira pela UNISINOS. Graduada em Letras pela UNISINOS.

${ }^{1}$ Como a concedida ao Jornal Folha de São Paulo: ELEK MACHADO, Cassiano. "Fado' ensaia todo Lobo Antunes, diz crítica. Jornal Folha de São Paulo, 03 ago. 2002, p. E12.
} 
Muito difícil é para o leitor formular uma síntese da obra, já que não existe um enredo no sentido tradicional do termo. Não há uma intriga com início, meio e fim. A memória é o fio condutor do relato das vozes que se revezam na narração. Ana Emília, viúva; Alice, exenfermeira e Osvaldo, seu marido e ex-policial da PIDE, são as vozes predominantes na narrativa, que se estrutura em seis grandes capítulos intitulados: Meia-noite, Uma hora da manhã, Duas horas da manhã, Três horas da manhã, Quatro horas da manhã e Cinco horas da manhã. Madrugada adentro, insones, as personagens recordam acontecimentos do passado de maneira muito fragmentada. Um episódio, em particular, parece unir as rememorações dos três: o suicídio da filha de Ana Emília, que aos quinze anos de idade, enforca-se numa macieira. As únicas testemunhas do fato, ocorrido há dois anos, são a boneca da menina e as árvores do quintal, elementos recorrentes no discurso das personagens.

A brutalidade, a dor e a morte perpassam todo o romance. Ana Emília é a voz que abre e fecha a narrativa, vive em Lisboa, é amante de Osvaldo, que não mais a visita, e viúva de outro agente, colega de Osvaldo, que por ele é assassinado, devido a razões políticas. Antes de morrer, o marido de Ana Emília é obrigado a vestir-se de mulher e a usar brincos. O suicídio da filha, o assassinato do marido, a espera pelo amante e a aparição inesperada de seu pai, que não via há muitos anos, constituem a temática de seu discurso.

Alice, a ex-enfermeira, vive em Évora, com o marido Osvaldo. É uma mulher de cinquenta e seis anos, que vive amargurada por ter abortado o filho, por influência do marido. A figura do berço, que apodrece jogado no pátio da casa, atormenta-a, assim como as lembranças da infância pobre, do pai abastado que não assumiu a sua paternidade, dos momentos de convivência com a mãe e com a avó, do tio querido que foi viver e morrer em Luxemburgo, das truculências do marido e do conhecimento da amante que ele visitava em Lisboa, cuja filha se suicidara.

Osvaldo, por sua vez, relembra a amante, o suicídio da menina para quem tinha dado a boneca e a morte da mãe:

Os parafusos da urna que uns sujeitos não acabavam de apertar (...) obrigando a madeira ou a minha mãe a estalarem e aí temos o exemplo de um capricho da memória que julgava perdido(...) um miúdo de três ou quatro anos de idade a pedir - não a esmaguem. (ANTUNES, 2006, p. 29)

O fechamento do caixão, que ele menino tentou impedir, segurando pelo brinco de sua mãe, o que acabou por rasgar-lhe a orelha, constitui a cena traumática que talvez explique 
as suas perversões. Como policial, torturava os presos, sodomizava-os e, antes de matá-los, fazia-os vestirem-se de mulher e usarem brincos:

\begin{abstract}
Os presos de lâmpada na cara vencidos e supondo que não vencidos os idiotas, que resistindo os palermas, que heróicos os cretinos e vencidos de facto, de pé junto ao ficheiro enganando-nos, mentindo, não conheço nada de explosivos senhor agente, não conheço nada de aviões, qual conspiração, qual jornal, sou despachante, sou mecanógrafo, trabalho nos seguros senhor agente, nunca ouvi nada disso (...) os presos o mesmo cheiro que a minha esposa (...) algo de mim para eles que me levava a morder-lhes os pescoços, os flancos, as minhas patas a escorregarem, a detestarem-nos (...) homens que se tornavam a minha mulher, eram a minha mulher (...) a trilhar-lhes as costas (...) aguentavam, curvavam-se, com o tubo de chumbo nas costelas (...) eu a proteger o País e eles de lâmpada na cara vencidos. (ANTUNES, 2006, p. 257)
\end{abstract}

Osvaldo recorda ainda de quando se descobriu filho bastardo de sua mãe, rejeitado pelo pai postiço e molestado sexualmente pela irmã. Não lida bem com as mulheres, nunca quis ter filhos e não dorme no mesmo quarto que a esposa:

\begin{abstract}
Não peço a uma mulher senão que tenha a casa em ordem e me deixe em paz. Pouca conversa, um quadrado de açúcar no caso de se portarem com juízo e aí as temos como deve ser evitando que nos ponham o pé em cima que é o sonho lá delas convencidas que o mundo lhes pertence (...) se levantarem o nariz finjo que não percebo e quando menos esperam nem são precisas palavras, basta um apertão bem dado e mais lágrima menos lágrima entram na linha outra vez, queres uma almofada para as costas, queres que feche a janela, nem um protesto se convocamos outra ao escritório (...) à noite a camisa de dormir levantada e o corpinho à espera, não exijo que me abracem, não lhes peço teatro, apenas que aguentem o serviço em silêncio, se afastem para o canto do colchão onde não se dê por elas. (ANTUNES, 2006, p. 55)
\end{abstract}

Ao lembrar os assassinatos de pessoas, que ele denomina "inimigos da Igreja e do Estado", mostra o prazer que sentia em cometer esses crimes, descrevendo seus requintes de crueldade. Pela voz de Osvaldo, o autor desvela a violência e a covardia da PIDE, retratando o terror da ditadura salazarista.

Um espaço é especialmente significativo na memória de agente aposentado, já que, no momento do relato de Osvaldo, a ditadura está terminada e, nas palavras dele, os inimigos da Igreja e do Estado estão no poder. Trata-se de Peniche, forte construído de 1557 a 1570 e que, no século XX, no período de 1930 a 1974, foi convertido em prisão política de segurança máxima. Peniche localiza-se no município de mesmo nome, na região da Leiria, a $80 \mathrm{~km}$ ao norte de Lisboa. Foi erguido sobre rochedos, em frente ao mar.

Lá aconteciam as sessões de tortura que Osvaldo impingia aos presos. Local da qual sente saudade: "A ideia de estar perto das pessoas sem que elas se apercebam desde sempre me agradou, sabê-las dependentes de mim, indefesas, utilizar a navalha, a pistola, o martelo" (ANTUNES, 2006, p. 279). Para as demais personagens, Peniche é um lugar que alimenta o 
imaginário sobre a morte do marido de Ana Emília e sobre o terror da ditadura de um modo geral:

Quem manda em Portugal é o doutor Salazar, a fotografia do doutor Salazar na parede maior que o crucifixo, o meu marido trabalhou para ele num forte à beira mar, uma praia de pescadores que não visitei nunca (...) Peniche, ondas a recuarem no sifão dos penedos. (ANTUNES, 2006, p. 222)

Todas as personagens, em sua noite de insônia, escutam as ondas batendo nos rochedos e o deslizar dos corpos dos presos, arremessados contra as rochas. Lobo Antunes introduz Peniche na narrativa como signo da história de violência do Estado Novo português, num ato de perpetuação da memória política do país, ou, de acordo com o conceito de reefetuação, de Paul Ricouer, trata, no presente, de um acontecimento historicamente conhecido, dando-lhe uma sobrevida que é a reefetuação em pensamento. O passado é irrevogável, mas “o sentido do que aconteceu não é determinado de uma vez por todas" (RICOEUR, 2007, p. 392) e, num gesto historiográfico, o passado surge como o "retorno" de possibilidades escondidas.

As três vozes que dividem a narração conhecem a história uma das outras. Apesar de se autonomearem e de relatarem fatos específicos de suas vidas entrelaçadas, o que se percebe, à medida em que se avança no texto, é que o discurso de todas apresenta um estilo muito semelhante e que algumas frases e pensamentos repetem-se de maneira integral em suas falas. Essas características acentuam-se no decorrer da obra, levando o leitor a cogitar que uma das vozes é a responsável pela narração, criando e dando voz às demais. Essa possibilidade reforça-se, pouco a pouco, quando as personagens confessam não estarem deitadas na cama, rememorando fatos passados, mas estarem a escrever as suas memórias pela madrugada adentro, numa insônia produtiva. No último capítulo, ou seja, às cinco da manhã, a voz de Alice nos diz:

E agora, pergunto, o que será de mim quando acabado este capítulo deixarem para sempre de me ouvir, quem se lembrará do que fui, demorará um instante a pensar e se preocupará comigo, ninguém se lembra, pensa, se preocupa, compram outros livros, esquecem-me e eu sozinha em páginas sem leitor algum continuando a acordar em Évora às oito da manhã e julgando que são cinco ao lado do meu marido que dorme, nunca tivemos cachorros nem piteiras nem malvas, moramos em Lisboa na casa que a minha mãe deixou, inventei tudo (...) a minha avó essa sim, habitou fora da muralha em Évora onde os ciganos passavam, falava-me de carroças e de gansos selvagens num pântano (...) portanto descrevi a casa de Évora ou o que das descrições da casa de Évora continua em mim, a bomba de gasolina, o telheiro e os corvos e provavelmente nem bomba de gasolina nem telheiro nem corvos existem salvo numa cabeça avariada que não se cala e me traz um berço e um pomar (...) somei-lhe o hospital (...) os meus alunos sem acreditarem em mim (...) só a parte do meu filho é autêntica mas deixemo-la de lado, custa-me, interrompi as aulas três dias, emagreci, perdi formas e a parteira a mostrar-me crostas numa 
bacia (...) sem que eu enxergue o motivo que me leva a falar disto, um segredo que nem ao meu marido contei (...) prefiro viver o que me acontece comigo, alguns episódios aliás nem comigo os vivo, recebo-os como aparecem, aceito-os mesmo que se me afigurem estranhos (...) ensino português e francês, o meu marido advogado, passamos férias em Peniche e daí o forte e as ondas e as pessoas que escorregam ao longo da parede. (ANTUNES, 2006, p. 381-384)

O leitor é desafiado a todo momento. Não há como confiar no que lhe é contado. O que é mentira? O que é verdade? Alice recorda, inventa e imagina. Joga a dúvida sobre o que já foi narrado. Constrói, destrói e reconstrói a si e aos outros: “Acreditem que não é um livro, sou eu" (ANTUNES, 2006, p. 392). As incertezas crescem, Alice volta para o relato anterior, busca prender a atenção de quem a lê:

A esperança que acabado este capítulo não deixarão para sempre de me ouvir, pensarão um instante, se lembrarão de mim, fui enfermeira no hospital de Évora e aqui onde estou, neste buraco da terra abaixo de vocês, abaixo ou acima de vocês, ao lado de vocês, neste buraco da terra ao lado de vocês vou sentindo a azinheira. (ANTUNES, 2006, p. 399)

Ao escrever, é como se Alice construísse uma sepultura, está enterrada, sente as raízes da azinheira, árvore plantada por sua avó na casa de Évora. Segundo Paul Ricouer (2007,p.370), a escrita enquanto movimento de retrospecção, de diálogo com os mortos e de ressignificação do passado, funciona como ato de sepultamento e de construção da memória. Alice constrói um túmulo escriturário não só para os seus mortos, mas também para si mesma, demonstrando a sua desesperança em relação ao presente e ao futuro.

Os mortos estão muito presentes na narrativa, perpetuam-se na memória das personagens, em cujo discurso, ganham voz: "Deve continuar a ter boca que os defuntos aqui não se calam” (ANTUNES, 2006, p. 391). Os narradores realizam a ressurreição literária dos mortos por meio da escrita memorialística que reconhece a presença da morte no meio dos vivos e reabre o passado sobre o presente. Essa escrita é ainda, além de rito de sepultamento e marca duradoura do luto, a busca pela construção de uma identidade própria, num resgate de algo de si:

O morto, aquele que não mais responde - constitui uma verdadeira amputação do si mesmo, na medida em que a relação com o desaparecido faz parte integrante da identidade própria. A perda do outro é, de certa forma, perda de si mesmo. (RICOEUR, 2007, p. 370)

Essa idéia da morte do outro como também uma espécie de morte de uma parte daqueles que ficam aparece no discurso de Osvaldo, como, por exemplo, quando ele relata a morte do pai: "O velho foi-se embora permanecendo ali, quer dizer os olhos tão acabados como o resto do corpo sem fitarem nada, a esquecerem-se, a impressão que não foi ele que cessou de existir, fomos nós" (ANTUNES, 2006, p. 364). 
Mortos e vivos, esses seres trazidos da memória, são representados, na narrativa, de modo a ressaltar o seu caráter humano, repletos de medos, fraquezas, defeitos e fragilidades, como assinala Paul Ricouer:

Os homens do passado foram, como nós, sujeitos de iniciativa, de retrospecção e de prospecção

(...) formularam expectações, previsões, desejos, temores e projetos. (RICOEUR, 2007, p. 393)

A grande complexidade do texto de Lobo Antunes se dá pela incerteza de qual voz funciona como autoconsciência geradora da textualidade, que cede espaço à voz do outro, pois o outro também pode vir a ser a voz configuradora. Essa idéia é fortemente sugerida, por exemplo, quando Alice cogita a possibilidade de ela mesma estar sendo narrada e configurada por uma outra autoconsciência e pensa em Ana Emília:

Quem me garante não ser a desconhecida a escrever isto por mim, conhece Évora, o pântano, sente a febre dos cachorros sob os planetas extintos, não consegue dormir (cinco da manhã para ela sem entender que dia e este livro acabado) (ANTUNES, 2006, p. 383)

A problematização de uma entidade responsável pelo todo da narrativa, pela criação das personagens e pela motivação de seus discursos se complica ainda mais no decorrer da obra. As vozes passam a apontar para um outro que os controla e que os obriga a escrever. Assim, Ana Emília afirma:

Escrevo que mirava a minha filha a odiar-me, se me dispensassem de continuar esta prosa aceitava

-Obrigada

tapava-me com a colcha, calava-me e se me riscarem do livro antes da manhã agradeço, siga a história sem mim. (ANTUNES, 2006, p. 169)

É Ana Emília a primeira a insinuar a construção de um romance, através da intromissão de uma voz que pode ou não ser da própria personagem: “Quem és tu Ana Emília responde, onde te fui buscar, de onde vens, por que razão me inquietas no livro? (...) isto é a vida, não um romance, se fosse um romance tudo perfeito, certo" (ANTUNES, 2006, p. 329). Ana Emília revolta-se contra o outro que a tenta manipular e quebra a repetição da informação das horas, que as vozes narradoras estavam a fazer em todos os capítulos: "Chegou a altura de dizer as horas mas não vou dizê-las, diga-as você se quiser, é o seu livro, mal o acabe deixei de existir como os infelizes dos livros anteriores e não me conhece mais" (ANTUNES, 2006, p. 330).

Osvaldo questiona por que escreve e, em meio ao seu discurso, há uma voz que lhe obriga a continuar o relato: "por que motivo escrevo a meu respeito" (ANTUNES, 2006, p. 280); "Não era nada do que escrevi até agora o que queria dizer" (ANTUNES, 2006, p. 285); 
“-Continue senhor e continuar o quê se não era uma linha do que escrevia até agora o que queria dizer" (ANTUNES, 2006, p. 294).

$\mathrm{Na}$ quarta parte, do capítulo "Quatro horas da manhã", o falecido marido de Ana Emília ganha voz e dialoga com um outro:

Por que não se calam os mortos e por que razão o mar não emudece de vez, quem me obriga a continuar sem descanso, me enterra o dedo no coração, agita lembranças (...) quatro da manhã, sei que dia, o seu livro quase no fim amigo, tantos meses para chegar aqui e duvidando se chegaria aqui. (ANTUNES, 2006, p. 357)

Este outro é nomeado pela personagem, que o chama de "António", e assim o autor real, António Lobo Antunes, é ficcionalizado e torna-se não só criador, mas também o interlocutor da personagem:

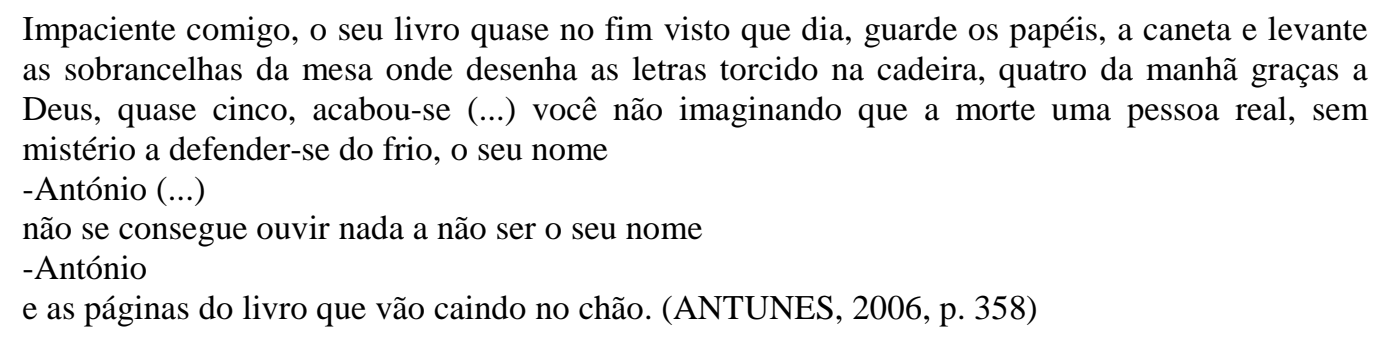

Alice, assim como fizera, Ana Emília, também fala de um romance e, em sua enunciação, identifica-se a discussão do que seja um romance:

Tudo para daqui a cinco ou seis páginas se não lembrarem de mim ou fazerem pouco -Um romance

e para quê um romance, o que tem a ver com a vida quando a vida precisamente indicações contraditórias e estradas erradas. (ANTUNES, 2006, p. 390)

Aborda ainda o trabalho do escritor, o processo criativo e, dessa forma, a narrativa dirige-se para o desfecho, assumindo um caráter metaficcional:

Páginas escritas a custo, emendadas, riscadas e emendadas de novo, passadas a limpo e ao lê-las -Não é assim

e continuar a escrever (...)

pergunto-me se inventei tudo ou estarão a inventar-me a escreverem a custo, a emendar, a riscar, a escreverem de novo, a passarem a limpo e ao ler

-Não é assim

de forma que tornando a escrever, escrevo (ANTUNES, 2006, p. 394-397).

Ana Emília, que abrira o romance, é a voz que o encerra: "E pronto, fico contente que tenha acabado" (ANTUNES, 2006, p. 401), mas em seu discurso final o leitor pode identificar a voz de sua filha, ou seja, da menina que se enforcara, e ela diz "Fico contente que tenha acabado, posso recomeçar do princípio" (ANTUNES, 2006, p. 402) e, assim, nada fica 
realmente acabado. As duas vozes se alternam. Ana Emília procura se eximir da missão de concluir o livro:

Cinco da manhã e acabou-se, a única coisa que me dizem é que cinco da manhã e acabou-se sem que eu compreenda o que se acabou, contem-me, cinco da manhã e então, no caso de não precisarem de mim posso dormir não posso? (...) O que me ordena que escreva foi-se embora e a mão da minha filha ou a minha (...) talvez uma criatura mais inteligente, mais capaz, devesse terminar este relato por mim. (ANTUNES, 2006, p. 412-415)

Ana Emília decide terminar o livro em nome da filha, concedendo-lhe voz: "Escrevo o fim deste livro em nome da minha filha que não pode escrever" (ANTUNES, 2006, p. 417). A menina passa a contar o episódio do suicídio a partir de seu ponto de vista, mas em meio à sua voz uma outra surge: "Chamo-me António Lobo Antunes, nasci em São Sebastião da Pedreira e ando a escrever um livro" (ANTUNES, 2006, p. 422). A menina passa a ver um homem que a olha e que a leva a escrever: "Não te incomodes que eu escrevo e não escrevia, fitava-me (...) escreve não importa o quê mas não pares (...) e a certeza de conhecê-lo (...) um senhor que me convoca" (ANTUNES, 2006, p. 430-431).

A intromissão do autor no texto problematiza a construção do espaço ficcional e os limites entre ficção e realidade. A narrativa densa e fragmentada, a polifonia confusa de sujeitos pulverizados, não permite ao leitor uma posição passiva perante o texto. As personagens são convocadas a rememorarem, a escreverem e o leitor é instigado a configurar este mundo de vozes e fragmentos e a construir-lhe um sentido. A grande significação da obra é dada pelo leitor que a interpreta: "O texto, enquanto escrita, espera e faz apelo a uma leitura; se a leitura é possível, é exactamente porque o texto não está fechado em si mesmo, mas aberto a outra coisa" (RICOEUR, 1989, p. 155).

Ao leitor cabe a tessitura da intriga e a configuração da narrativa, "o texto só se torna obra na interação entre texto e receptor" (RICOEUR, 1994, p. 118), pois "seguir uma história é atualizá-la na leitura” (RICOEUR, 1994, p. 118). Em Tempo e Narrativa, Paul Ricouer afirma que há obras que não visam esclarecer, mas obscurecer. Em Ontem não te vi em Babilônia, nada fica claro, nem com o alvorecer, e a última frase do romance avisa: "aquilo que escrevo pode ler-se no escuro" (ANTUNES, 2006, p. 435).

\section{Referências}

ANTUNES, António Lobo. Ontem não te vi em Babilônia. Rio de Janeiro: Objetiva, 2006. 
RICOEUR, Paul. A memória, a história e o esquecimento. Trad. François Alain P. Campinas: Unicamp, 2007.

. Do texto à acção: ensaios de hermenêutica II. trad. de Alcino Cartaxo e Maria José Sarabando. Porto: Seuil, 1989.

Tempo e Narrativa: Tomo I. Tradução: Constança Marcondes Cesar, Marina Appenzeller, Roberto Leal Ferreira. Campinas: Papirus, 1994. 